\title{
Sedimentary record of coseismic subsidence in Hersek coastal lagoon (Izmit Bay, Turkey) and the late Holocene activity of the North Anatolian Fault
}

\author{
Sébastien Bertrand \\ Department of Geography and Earth Sciences and Institute for the Environment, Brunel University, \\ Uxbridge UB8 3PH, UK \\ Now at Renard Centre of Marine Geology, University of Ghent, Krijgslaan 281 S8, 9000 Gent, \\ Belgium (sbertrand@whoi.edu)
}

Lisa Doner

Center for the Environment, Plymouth State University, Plymouth, New Hampshire 03264, USA

(ladoner@plymouth.edu)

\section{Sena Akçer Ön and Ummuhan Sancar \\ EMCOL and General Geology Section, Faculty of Mines, Istanbul Technical University, 34469 \\ Istanbul, Turkey (akcer@itu.edu.tr; sancarum@itu.edu.tr)}

\section{Ulla Schudack and Steffen Mischke}

Institute of Geological Sciences, Freie Universität Berlin, D-12249 Berlin, Germany

(palus@zedat.fu-berlin.de; smischke@zedat.fu-berlin.de)

\section{Namik Çagatay}

EMCOL and General Geology Section, Faculty of Mines, Istanbul Technical University, 34469 Istanbul,Turkey(cagatay@itu.edu.tr)

\section{Suzanne A. G. Leroy}

Department of Geography and Earth Sciences and Institute for the Environment, Brunel University, Uxbridge UB8 3PH, UK (Suzanne.Leroy@brunel.ac.uk)

[1] The late Holocene activity of a restraining bend of the northern strand of the North Anatolian Fault in Izmit Bay was investigated by a sedimentological, geochemical, and paleoecological analysis of sediment cores from Hersek coastal lagoon, NW Turkey. The sediment cores show a succession of sedimentary sequences composed of three units separated by gradual transitions. The first unit is composed of a thin layer of shell debris-rich sediment in abrupt contact with the underlying organic-rich deposits. This unit is overlain by a thick foraminifera-rich mud deposit, and the sequences are capped by an organic-rich mud unit. These sequences are interpreted as silting up, shallowing upward deposits, typical of a lagoon becoming isolated from the sea. We suggest that they represent the sedimentary signature of coseismic subsidence, which was caused by reverse slip at the Hersek bend, and tsunamis in Izmit Bay. Our radiocarbon-dated paleoseismological record indicates (1) the atypical collapse of the hanging wall during the 740 earthquake and (2) subsidence of the footwall during the 987, 1509, and 1719 earthquakes. This study contributes to the understanding of the dynamics of restraining bends, and it highlights the potential of coastal sediments for reconstructing past earthquakes and tsunamis in regions dominated by strike-slip deformations. 
Components: 10,300 words, 7 figures, 2 tables.

Keywords: North Anatolian Fault; coastal lagoon; coseismic subsidence; tsunami.

Index Terms: 4217 Oceanography: General: Coastal processes; 4863 Oceanography: Biological and Chemical: Sedimentation (1861); 7221 Seismology: Paleoseismology (8036).

Received 11 January 2011; Revised 31 March 2011; Accepted 31 March 2011; Published 10 June 2011.

Bertrand, S., L. Doner, S. Akçer Ön, U. Sancar, U. Schudack, S. Mischke, M. N. Çagatay, and S. A. G. Leroy (2011), Sedimentary record of coseismic subsidence in Hersek coastal lagoon (Izmit Bay, Turkey) and the late Holocene activity of the North Anatolian Fault, Geochem. Geophys. Geosyst., 12, Q06002, doi:10.1029/2011GC003511.

\section{Introduction}

[2] The North Anatolian Fault (NAF) is one of the most seismically active structures in the world. It is a major right-lateral moving fault that runs along the tectonic boundary between the Eurasian Plate to the north and the Anatolian Plate to the south. The western segment of the NAF splits into three main branches [Armijo et al., 2002]. The northern one (NNAF) is the most active [Hubert-Ferrari et al., 2000]. It passes through Izmit Bay and traverses the Sea of Marmara (Figure 1), accommodating more than $80 \%$ of the current relative plate motion [McClusky et al., 2000]. The northern strand of the NAF is generally subdivided in several subsegments that have been the source of numerous large historical earthquakes [e.g., Ambraseys and Jackson, 2000; Ambraseys, 2002]. The most recent major earthquake in the region occurred in Izmit on 17 August 1999 [Barka, 1999]. It was the latest earthquake in a series of seven westward migrating earthquakes caused by dextral strike-slip ruptures of the NAF, and it was accompanied by extensive surface rupture, consisting primarily of right-lateral strike-slip displacement of up to $5.2 \mathrm{~m}$ [Barka et al., 2002].

[3] In Izmit Bay, the NNAF consists of three subsegments linked by bends [Cormier et al., 2006] (Figure 1c). The Karamürsel and Darica segments merge on Hersek Peninsula, which was formed by tectonic uplift of Quaternary deposits at a left stepping $7^{\circ}$ restraining bend [Cormier et al., 2006]. This bend is believed to have acted as a local barrier to westward rupture propagation, especially during the 1999 Izmit earthquake [Kozaci et al., 2011]. In the near future, the Darica segment is the most likely to rupture, as part of the sequence of westward migrating earthquakes [Barka, 1999; Hubert-Ferrari et al., 2000]. It poses a significant earthquake hazard to Istanbul and surrounding densely populated areas [Witter et al., 2000].
[4] Izmit Bay is also prone to tsunami. The 1999 Izmit earthquake, for example, caused a damaging tsunami with runups of $1-2.5 \mathrm{~m}$ in most of the bay [Altinok and Ersoy, 2000; Altinok et al., 2001; Rathje et al., 2004; Tinti et al., 2006]. It was very likely caused by the combined effect of coseismic vertical deformations and local mass failure (submarine slump) [Tinti et al., 2006] and was accompanied by coastal landslides and subsidence [Altinok et al., 2001].

[5] Although Turkish historical data documenting past earthquakes and tsunamis are available and relatively reliable for the last centuries [e.g., Ambraseys and Jackson, 2000; Ambraseys, 2001], a longer record is needed to tackle questions about the frequency of great earthquakes, and their potential to trigger tsunamis and associated land movements. Other sources of information are also needed to verify and complement the historical data.

[6] In an attempt to reconstruct the past seismic activity of Hersek bend, Witter et al. [2000] and Kozaci et al. [2011] excavated several paleoseismic trenches on Hersek Peninsula. Although these trenches confirmed that the NNAF crosses the peninsula and forms a local restraining bend, the interpretation of the stratigraphic horizons was complicated by their close association with anthropogenic features, and the site did not provide useful stratigraphic data to assess the timing of the most recent earthquakes [Witter et al., 2000; Kozaci, 2002; Kozaci et al., 2011]. More recently, Özaksoy et al. [2010] studied the uplifted marine terraces that compose the Hersek Peninsula north of the restraining bend. They suggest that the terraces represent four subsequent events of late Holocene tectonic uplift, separated by a subsidence event of $\sim 1.2 \mathrm{~m}$ during the 15 th century. The youngest marine terrace was associated to the 1509 earthquake. In addition, McHugh et al. [2006] analyzed marine sediment cores collected on the submarine 

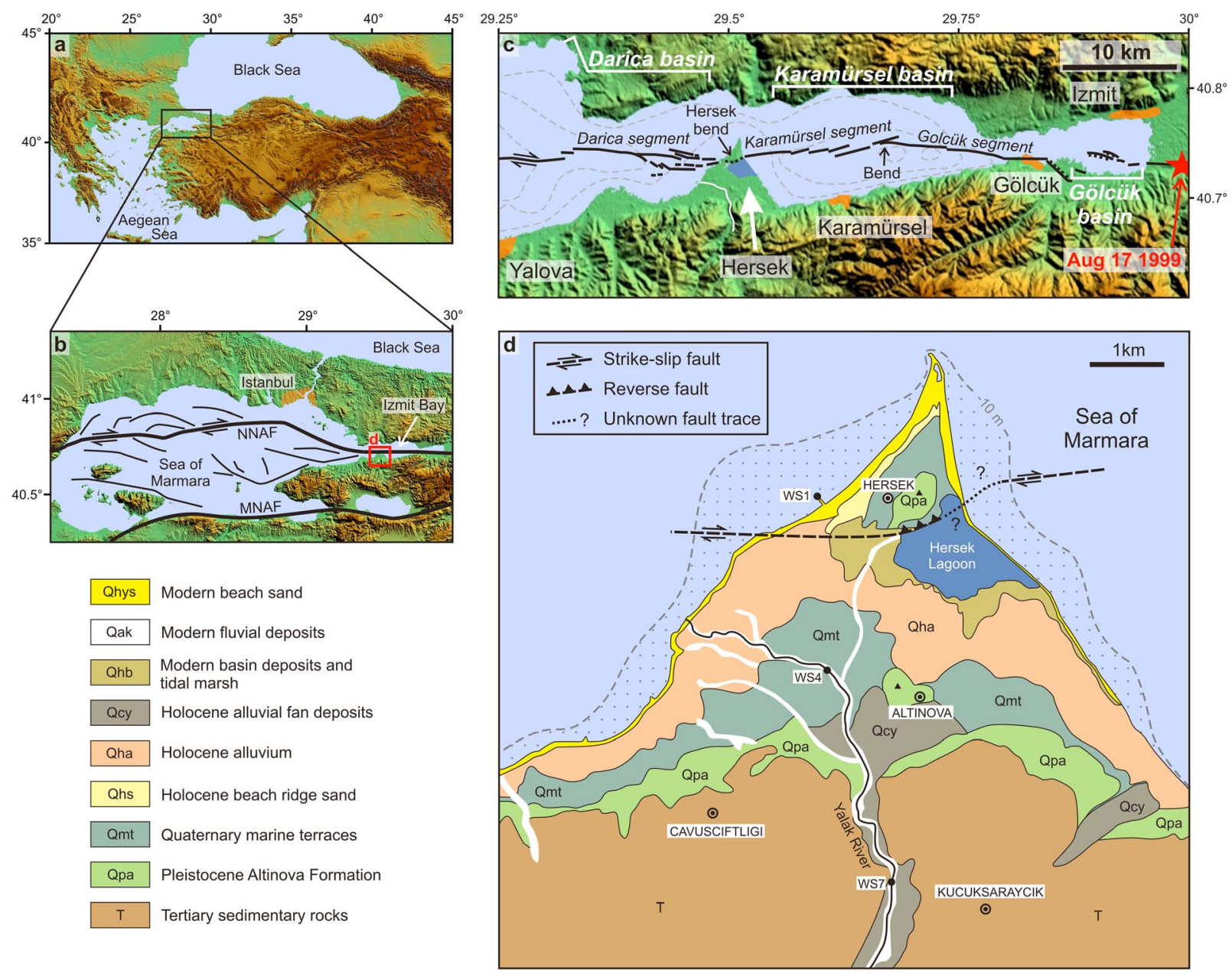

Figure 1. (a, b) Location of Izmit Bay in the Sea of Marmara, Turkey. The northern (NNAF) and middle (MNAF) branches of the North Anatolian Fault are schematically drawn according to Armijo et al. [2002] and Hergert and Heidbach [2010]. (c) Location of the NNAF fault segments in Izmit Bay (labeled in italics), according to Kuşçu et al. [2002], Cormier et al. [2006], and Özaksoy et al. [2010]. Note the restraining bends linking the fault segments. (d) Geological map of Hersek Peninsula, based on Witter et al. [2000] and Kozaci [2002]. The fault geometry is drawn according to Cormier et al. [2006], Özaksoy et al. [2010], and Kozaci et al. [2011]. The bathymetric contour line delimits the occurrence of shell-rich sand deposits between 0 and -10 m [Eryilmaz et al., 1995]. Sites WS1, WS4, and WS7, where $\mathrm{pH}$ and salinity were measured are also indicated (data shown in Figure 2).

slope of Hersek Peninsula to reconstruct masswasting events triggered by earthquakes in Izmit Bay. These authors tentatively attribute a masswasting deposit to the major 1509 earthquake but the deposits do not provide information regarding older events.

[7] Surprisingly, very little attention has been paid to the sediments deposited in the coastal environments of the Sea of Marmara although Witter et al. [2000] recognize that marsh stratigraphic studies might reveal more information about past surface ruptures than trenches. In other regions of the world, coastal deposits have successfully been used to reconstruct past tsunamis [e.g., Bondevik et al., 1997; Fujiwara et al., 2000; Pinegina et al., 2003; Cisternas et al., 2005; Kelsey et al., 2005] and coseismic subsidence [Atwater, 1987; Hayward et al., 2006; Shennan and Hamilton, 2006; Nelson et al., 2008] using lithological and paleoecological analyses (diatoms and foraminifera), combined with radiocarbon dating.

[8] This study of Hersek Lagoon aims at (1) understanding the sedimentary processes in the lagoon and (2) reconstructing the late Holocene activity of Hersek restraining bend through a multiproxy analysis of the lagoon sedimentary 


\begin{tabular}{|c|c|c|}
\hline Site & $\mathrm{pH}$ & $\begin{array}{c}\text { Salinity } \\
\text { (ppt) }\end{array}$ \\
\hline \multicolumn{3}{|c|}{ Sea of Marmara } \\
\hline WS1 & 8.20 & 24.17 \\
\hline WS10 & 8.27 & 24.60 \\
\hline WS11 & 8.27 & 24.65 \\
\hline \multicolumn{3}{|c|}{ Yalak River } \\
\hline WS4 & 7.04 & 0.27 \\
\hline WS7 & 7.87 & 0.25 \\
\hline \multicolumn{3}{|c|}{ Hersek lagoon } \\
\hline WS2 & 8.76 & 39.11 \\
\hline WS3 & 8.59 & 39.94 \\
\hline WS5 & 9.37 & 38.72 \\
\hline WS6 & 9.20 & 38.35 \\
\hline WS8 & 8.16 & 28.98 \\
\hline WS9 & 8.20 & 28.01 \\
\hline WS12 & 8.58 & 28.87 \\
\hline WS 13 & 8.82 & 30.48 \\
\hline WS14 & 8.85 & 29.29 \\
\hline WS15 & 8.83 & 28.66 \\
\hline WS16 & 9.04 & 28.83 \\
\hline$\Longrightarrow$ & \multirow{2}{*}{\multicolumn{2}{|c|}{$\begin{array}{l}\text { Strike-slip fault } \\
\text { Reverse fault }\end{array}$}} \\
\hline A. Reverse fault & & \\
\hline$\ldots ? ?$ & known & trace \\
\hline
\end{tabular}

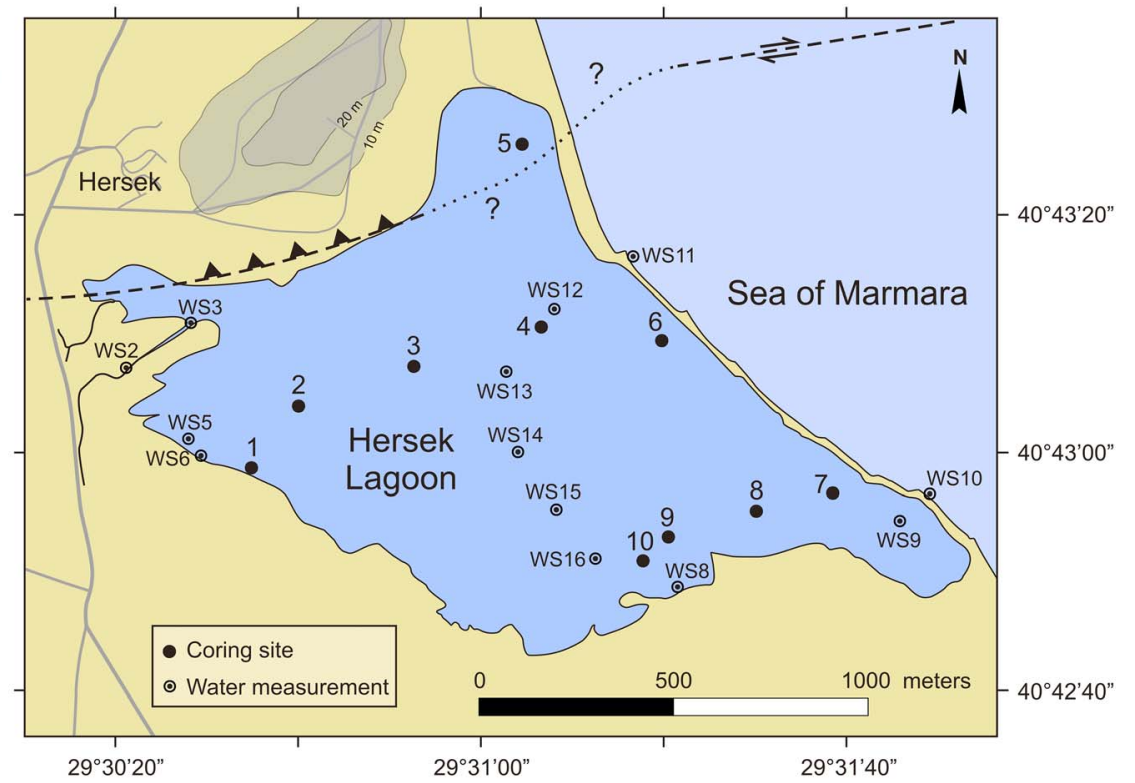

Figure 2. Location of the 10 piston cores retrieved in Hersek Lagoon (dots labeled from 1 to 10). The spots labeled WSx correspond to sites where $\mathrm{pH}$ and salinity were measured in July 2005 using an YSI multiprobe. Water properties were measured in Hersek Lagoon, in the Sea of Marmara, and in the Yalak River. Sites WS1, WS4, and WS7 are located in Figure 1. The North Anatolian Fault trace, including the Hersek restraining bend, is located according to Özaksoy et al. [2010] and Kozaci et al. [2011].

infill. Our results, which combine lithology, geochemistry, mineral magnetism, paleoecology and radiocarbon dating, provide evidence for several seismotectonic events that triggered coseismic subsidence of Hersek Lagoon during the late Holocene, revealing important information about the behavior of restraining bends during major earthquakes.

\section{Location and Geological Setting}

[9] Hersek Lagoon is a small (surface area $1.4 \mathrm{~km}^{2}$ ) and very shallow $(50-60 \mathrm{~cm})$ coastal lagoon located on the southern shore of Izmit Bay, which is the continuation of the Sea of Marmara to the east (Figure 1). It is the westernmost place where the North Anatolian Fault can be studied on land before in enters into the Sea of Marmara [Kozaci et al., 2011].

[10] Hersek Lagoon is separated from the adjacent Sea of Marmara by a sandy coastal barrier that has been reinforced in its center by a low-elevation concrete dike. The date of the construction of the dike is unknown but it is believed to date from the 1950 to 1975 period. The concrete dike is breached at several locations, allowing a continuous exchange of water between the lagoon and the Sea of Marmara. Hersek Lagoon is part of Hersek Pen- insula $\left(25 \mathrm{~km}^{2}\right)$, which comprises an area uplifted by the NAF to the north and Quaternary alluvial deposits to the south [Alpar and Güneysu, 1999; Özaksoy et al., 2010] (Figure 1d). Although the modern Yalak River flows directly to the western shore of the Peninsula, remains of ancient stream channels that connected the river to Hersek Lagoon are visible (Figure 1d).

[11] The northern part of Hersek Peninsula is crossed by the Hersek restraining bend, which links the Karamürsel and Darica segments of the NNAF and likely acts as a barrier in the propagation of fault rupture [Özaksoy et al., 2010; Kozaci et al., 2011] (Figure 1). The exact fault trace on the peninsula is unknown, but extrapolations of the submarine branches imply a $7^{\circ}$ bend across the peninsula [Cormier et al., 2006]. Recent studies have demonstrated that Hersek bend is characterized by reverse slip deformations, resulting in the uplift of a ridge at a rate of $3.5 \mathrm{~m} / \mathrm{kyr}$ north of the fault [Özaksoy et al., 2010], and in the subsidence of Hersek Lagoon south of it [Kozaci et al., 2011] (Figures 1 and 2). Except for this small ridge that reaches $27 \mathrm{~m}$ a.s.l. (Figure 2), the topography of Hersek Peninsula around the lagoon is very flat, with a mean elevation of 2-3 $\mathrm{m}$ a.s.l. 
Table 1. Location and Physical Characteristics of the 10 Sediment Cores Collected in Hersek Lagoon, NW Turkey

\begin{tabular}{lcccc}
\hline Coring Site & Latitude $\left({ }^{\circ} \mathrm{N}\right)$ & Longitude $\left({ }^{\circ} \mathrm{E}\right)$ & Water Depth $(\mathrm{cm})$ & Length of Composite Core $(\mathrm{cm})$ \\
\hline HK04LV1 & $29^{\circ} 30.577^{\prime}$ & $40^{\circ} 42.980^{\prime}$ & 40 & 74 \\
HK04LV2 & $29^{\circ} 30.663^{\prime}$ & $40^{\circ} 43.066^{\prime}$ & 36 & 99.5 \\
HK04LV3 & $29^{\circ} 30.873^{\prime}$ & $40^{\circ} 43.121^{\prime}$ & 42 & 141.5 \\
HK04LV4 & $29^{\circ} 31.106^{\prime}$ & $40^{\circ} 43.176^{\prime}$ & 65 & 350.5 \\
HK04LV5 & $29^{\circ} 31.071^{\prime}$ & $40^{\circ} 43.431^{\prime}$ & 47 & 352 \\
HK04LV6 & $29^{\circ} 31.326^{\prime}$ & $40^{\circ} 43.157^{\prime}$ & 61 & 375 \\
HK04LV7 & $29^{\circ} 31.638^{\prime}$ & $40^{\circ} 42.944^{\prime}$ & 52 & 239.5 \\
HK04LV8 & $29^{\circ} 31.498^{\prime}$ & $40^{\circ} 42.919^{\prime}$ & 61 & 180 \\
HK04LV9 & $29^{\circ} 31.338^{\prime}$ & $40^{\circ} 42.883^{\prime}$ & 54 & 131 \\
HK04LV10 & $29^{\circ} 31.291^{\prime}$ & $40^{\circ} 42.850^{\prime}$ & 49 & 106 \\
\hline
\end{tabular}

[12] The impact of the 17 August 1999, Mw 7.4 Izmit earthquake on Hersek Peninsula is controversial. Witter et al. [2000] observe no significant surface rupture during or following the event, in agreement with Lettis et al. [2002] who show that the surface rupture ended at the eastern margin of Hersek Peninsula and did not involve the Darica segment. However, Barka et al. [2002] report that the Darica segment constitutes the westernmost limit of the 17 August 1999 rupture zone, although no significant lateral movements were observed. Lettis et al. [2002] also mention that minor vertical deformations affected Hersek Peninsula during or immediately after the 1999 Izmit earthquake, and that Hersek Lagoon subsided by about $20-30 \mathrm{~cm}$ but had rebounded after two months. No surface rupture was reported on Hersek Peninsula during the series of westward migrating earthquakes that affected the region between 1939 and 1996 [Barka, 1996; Witter et al., 2000]. Historical records suggest that the Darica fault segment may have suffered surface rupture during major earthquakes in 1509, 1719 and 1894 [Barka and Kadinsky-Cade, 1988; Ambraseys and Finkel, 1990, 1991], although it is not known if this included surface rupture on Hersek Peninsula [Witter et al., 2000]. The 1509 Istanbul earthquake, which is considered as one of the most destructive events in the Sea of Marmara region [McHugh et al., 2006], seems to have significantly affected Hersek Peninsula, as it is responsible for the destruction of Hersek mosque, located on the northwestern shore of the lagoon [Witter et al., 2000].

\section{Material and Methods}

[13] Ten sediment cores were retrieved from Hersek Lagoon in July 2004 (Table 1). All sediment cores were split into two identical halves and analyzed for volume specific magnetic susceptibility at $5 \mathrm{~mm}$ resolution. The two longest cores
(HK04LV5 and HK04LV6), which were retrieved from the northern and southern side of the suggested trace of the restraining bend (Figure 2), respectively, were sampled for multiproxy sedimentological, geochemical and paleoecological analyses.

[14] Two $\mathrm{cm}$ thick slices of sediment were taken at $10 \mathrm{~cm}$ intervals in the first core half. These samples were analyzed for bulk and clay mineralogy, mineral magnetism (ARM, IRM), and organic (TOC) and inorganic (TIC) carbon contents. In addition, $\mathrm{C} / \mathrm{N}$ ratios and Sulfur concentrations were measured on samples from core HK04LV5. These analyses aimed at reconstructing changes in the sources of sediment and in the nature of the depositional environments. Sulfur concentrations were used as a proxy for marine transgressions in coastal environments [Berner and Raiswell, 1984; $\mathrm{Ku}$ et al., 2001]. Analytical details are given in Text S1 in the auxiliary material. ${ }^{1}$

[15] The second core half was continuously sampled in $5 \mathrm{~cm}$ slices and these samples were wet sieved at 63,250 and $500 \mu \mathrm{m}$. Foraminifera were determined on the 63-500 $\mu \mathrm{m}$ fraction of core HK04LV6 and ostracod absolute shell abundances were determined on the $>250 \mu \mathrm{m}$ fraction of core HK04LV5. The $>500 \mu \mathrm{m}$ fraction of cores HK04LV5, 6 and 7 was used (1) to determine and quantify the nature of the coarse particles (intact and broken mollusk shells, mollusk shell fragments and organic matter fragments) under a binocular lens and (2) to handpick macroscopical remains of terrestrial organic matter for radiocarbon analysis.

[16] The radiocarbon age of organic debris from all the organic-rich layers of cores HK04LV5, 6 and 7, was determined by AMS (9 samples). Calendar ages were obtained by calibration with OxCal 4.0 using the IntCal04 atmospheric calibration curve of Reimer et al. [2004]. The dated material is believed

\footnotetext{
${ }^{1}$ Auxiliary materials are available in the HTML. doi:10.1029/ 2011 GC003511.
} 

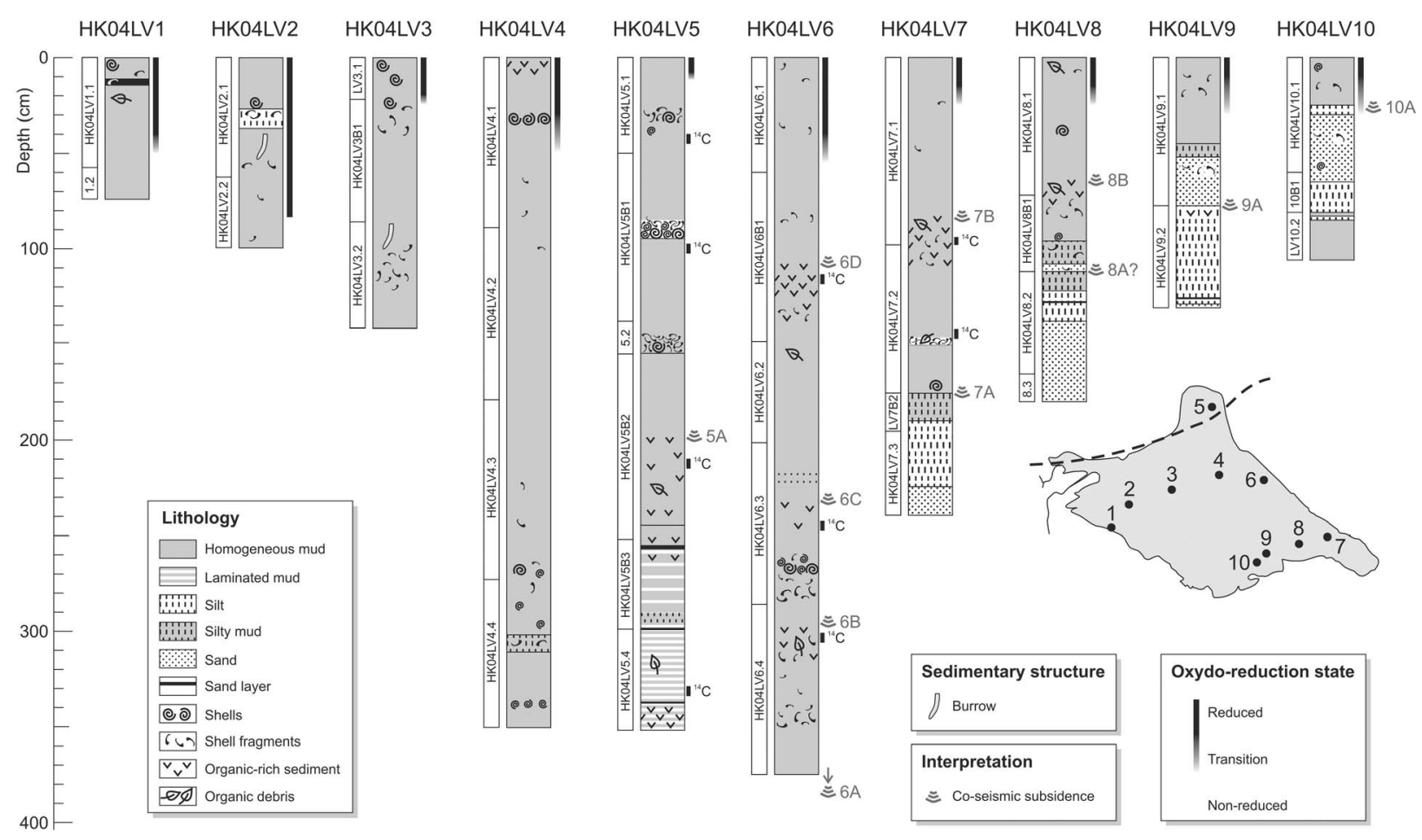

Figure 3. Lithology of the 10 sediment cores collected in Hersek Lagoon. The intervals sampled for radiocarbon analysis are also indicated. The radiocarbon ages are given in Table 2.

to represent in situ terrestrial vegetation that was buried by the overlying sediments.

\section{Results}

\subsection{Lithostratigraphy and Magnetic Susceptibility}

[17] The composite core lengths vary from $74 \mathrm{~cm}$ (HK04LV1) to $375 \mathrm{~cm}$ (HK04LV6). The sediment is generally composed of homogenous dark gray to greenish gray mud (Figure 3), although the bases of cores collected in the southern part of the lagoon (cores 7 to 10) are silty or sandy. Several shell-rich or sand/silt layers occur throughout the cores, and organic-rich layers have been observed in cores 5 to 8 (Figure 3). Magnetic susceptibility (MS) values are generally low (i.e., under $100 \times 10^{-6}$ S.I.), except at the base of cores 5 and 7-10, where values reach $300 \times 10^{-6}$ S.I. (Figures 4 and 5). The lower MS values are typical of muddy sediment rich in carbonate and organic matter, and from pyritization of magnetite in sulfur- and iron-rich reducing conditions of saline lagoons. Shell layers are generally represented by extremely low MS values. They are composed of fragmented bivalves (Cardium, Scro- bicularia) and intact and fragmented gastropods (Bittium reticulatum, Hydrobia, Patella, Turitella), although a few specimens of articulated Cardium were also observed.

\subsection{Mineralogy and Mineral Magnetism}

[18] Bulk mineralogy is dominated by clay minerals $(60 \pm 16 \%$ in HK04LV5; $56 \pm 17 \%$ in HK04LV6). The secondary minerals are quartz and plagioclase (anorthite), increasing at the base of core 5 (Figures 4 and 5). Halite, calcite and aragonite occur in lower proportions. Aragonite is absent from the lower half of core HK04LV5. Sporadic decreases in total clay minerals are associated with shell- or organic-rich layers.

[19] In both cores, the clay mineralogy is dominated by smectite $(70 \pm 6 \%$ in core 5 and $66 \pm 10 \%$ in core 6), with a sharp increase at the base of core 5 (Figure 4). The other clay minerals are illite $(24 \pm$ $5 \%$ in core $5,27 \pm 10 \%$ in core 6 ) and traces of chlorite and kaolinite (less than 5\%).

[20] In core HK04LV5, the S parameter ranges from 0.9 to 1 below $200 \mathrm{~cm}$ and from 0.65 to 0.8 above $200 \mathrm{~cm}$, with two exceptions at 280 and 


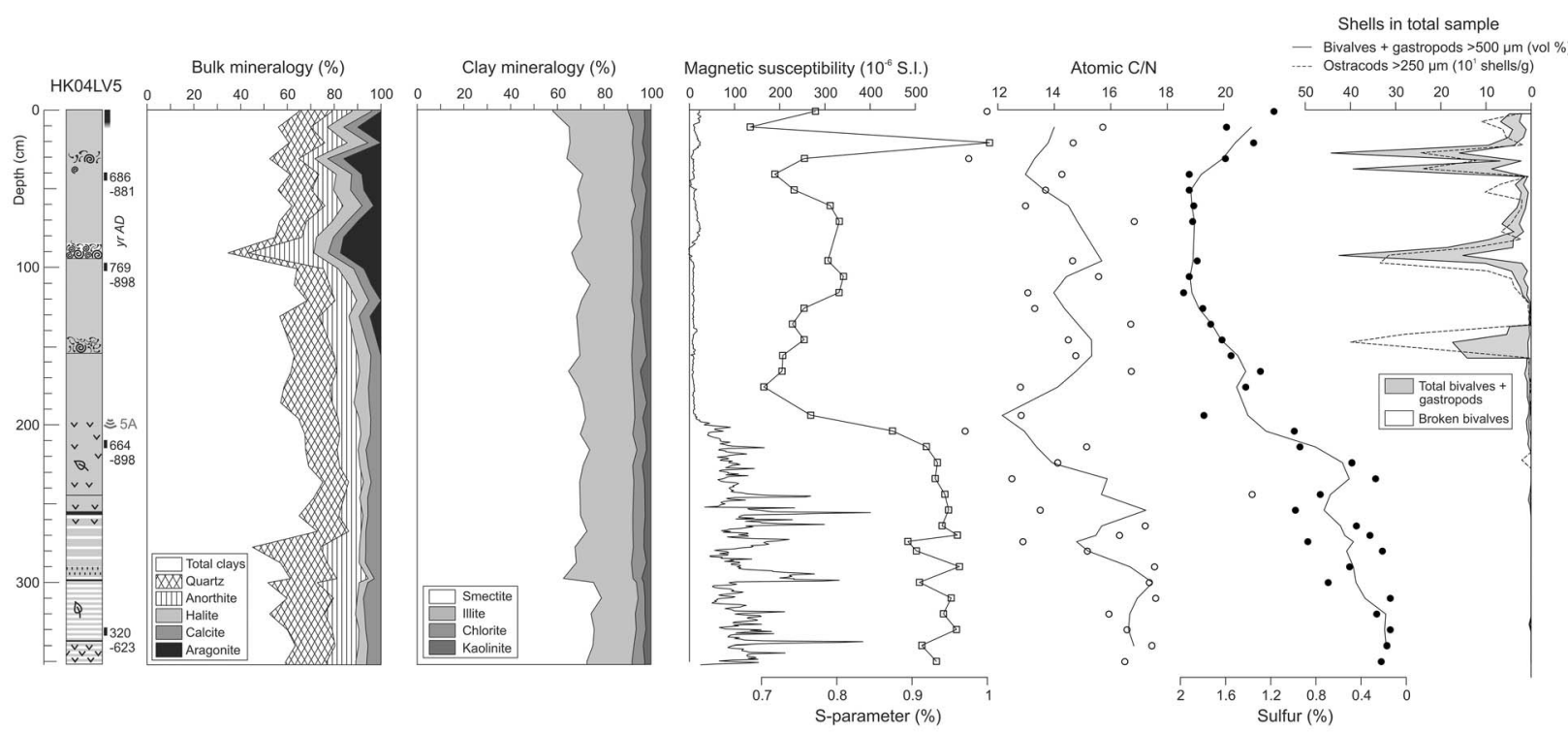

Figure 4. Results obtained on core HK04LV5. For sulfur concentrations and C/N data, the curves represent threepoint running averages.

$20 \mathrm{~cm}$ (Figure 4). The shift at $200 \mathrm{~cm}$ most likely reflects a change in sediment source.

\subsection{Geochemistry}

[21] TOC in core HK04LV5 varies from 0.75 to $2.23 \%$, and is significantly higher above $200 \mathrm{~cm}$
$(1.40 \pm 0.32 \%)$ than below $200 \mathrm{~cm}(0.97 \pm 0.10 \%)$. Similarly, the atomic $\mathrm{C} / \mathrm{N}$ values are higher under $200 \mathrm{~cm}(15.7 \pm 2.4)$ than above $200 \mathrm{~cm}(14.2 \pm 1.7$; Figure 4). The $\mathrm{CaCO}_{3}$ values are relatively stable through the profile $(5.3 \pm 1.4 \mathrm{wt} \%)$, except within the three shell layers, where they increase above $20 \%$ (not shown). The sulfur content ranges from

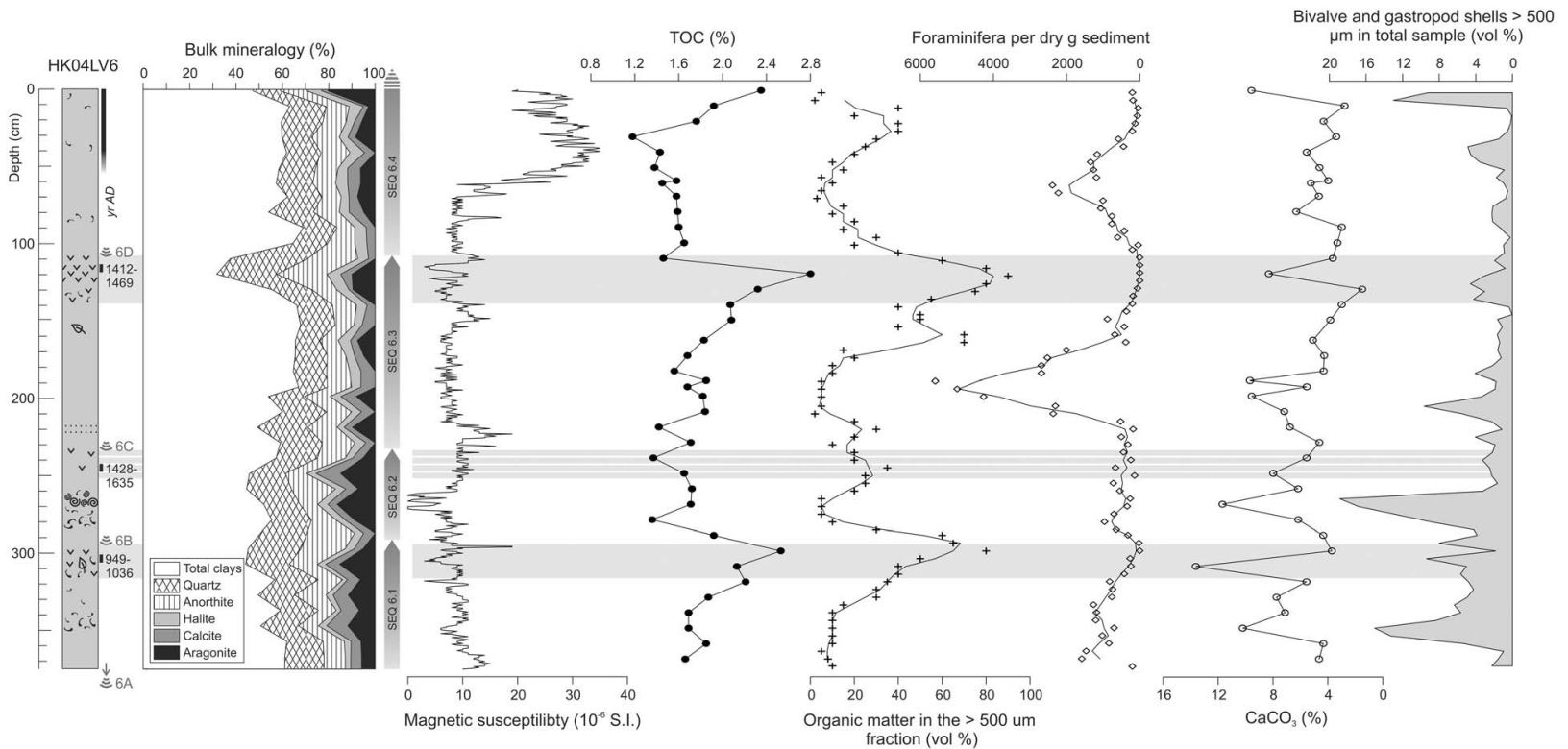

Figure 5. Results obtained on core HK04LV6. For the coarse organic matter content data and the foraminifera abundance, the curves represent three-point running averages. Horizontal gray-shaded rectangles indicate intervals with high organic matter content and low foraminifera abundances, with the striped gray band representing a poorly developed organic horizon. SEQ 6.1 to 6.4 represents the sedimentary sequences defined in section 5.2. 


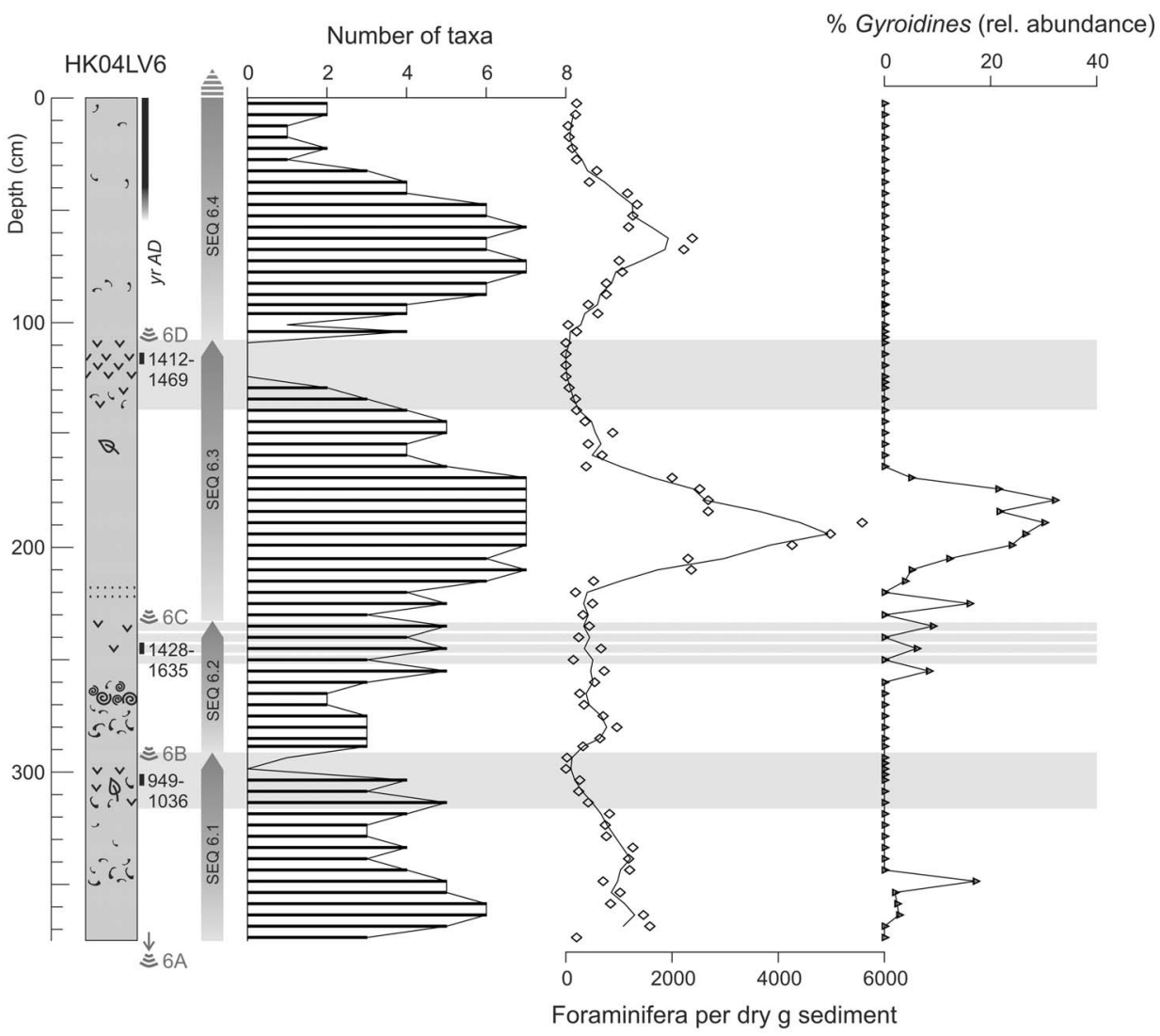

Figure 6. Foraminifera data for core HK04LV6. The number of foraminifera taxa is used here as a proxy for diversity. A total of 10 species was identified. The curve corresponding to the number of foraminifera per dry $g$ of sediment is a three-point running average.

$0.07 \%$ to $1.9 \%$, with an abrupt increase at $200 \mathrm{~cm}$, from $0.42 \pm 0.31 \%$ under $200 \mathrm{~cm}$ to $1.61 \pm 0.25 \%$ above $200 \mathrm{~cm}$ (Figure 4).

[22] By comparison, TOC in core HK04LV6 oscillates between 1.18 and $2.80 \%$ and shows three increasing upward sequences. Two of these sequences end with abrupt TOC minima at $290 \mathrm{~cm}$ and $115 \mathrm{~cm}$ (Figure 5). The TOC profile closely parallels the amount of coarse $(>500 \mu \mathrm{m})$ organic matter debris (Figure 5), mainly composed of marsh plant fragments. The $\mathrm{CaCO}_{3}$ content is highly variable with no clear trend with depth $(5.8 \pm 2.6 \mathrm{wt} \%$; Figure 5), and is roughly conform to the amount of coarse shells in the samples (Figure 5).

\subsection{Paleoecology}

[23] In core HK04LV5, ostracod abundance shows a sharp transition from virtually absent below $155 \mathrm{~cm}$ to extremely abundant above $155 \mathrm{~cm}$ (average 99 shells/g sediment), peaking at 250-400 shells/g in the coarse shell layers (Figure 4). The ostracod assemblages are clearly dominated by Cyprideis torosa $(95.3 \%)$.

[24] Benthic foraminifera occur throughout core HK04LV6, except within the organic-rich zones at $301-296 \mathrm{~cm}$ and $120-106 \mathrm{~cm}$, which contain no foraminifera (Figure 5). The most abundant types are Haynesina depressula, Ammonia tepida, Ammonia infilata, Gyroidinoides lamarckiana, Elphidium sp., and Ammonia sp. A few specimens of Elphidium macellum, Elphidium margeritaceum, Nonion depressulum and Nonion fabum were also identified. Planktonic foraminifera are very rare. Total foraminifera abundances vary considerably throughout core HK04LV6, with a pronounced maximum at 212-165 cm (Figures 5 and 6), which interestingly corresponds to the sole significant occurrence of Gyroidinoides (Figure 6). The total abundance data show secondary increases at 80 $45 \mathrm{~cm}$ and at the base of the core (Figure 6). The three foraminifera-rich intervals are characterized 
by high numbers of foraminifera taxa (used here as a proxy for diversity).

\section{Interpretation}

\subsection{Modern Sedimentation and Sediment Sources}

[25] Water parameters from 11 sites (i.e., $\mathrm{pH}$ and salinity; Figure 2) and field observations in July 2005 indicate that Hersek Lagoon is no longer fed by the Yalak River (Figure 1). The modern Hersek Lagoon is primarily fed by the Sea of Marmara, through breaches in the coastal barrier on the eastern side of the lagoon (Figure 2). It is a semienclosed (following Bird [1994]) and slightly evaporitic basin, as evidenced by the high salinity of the lagoon's water (28-31\% with maxima reaching 40\%o at its western shore and in the paleoYalak River channels; Figure 2) compared to that of the Sea of Marmara ( 24\%o). It is believed that the sediment that accumulates in the lagoon originates from the Sea of Marmara, and is carried into the lagoon by tidal currents and waves.

[26] The geological map of Hersek Peninsula (Figure 1) and field observations indicate that the lagoon was once directly fed by Yalak River, which would have been a significant additional source of sediment. The timing of the river disconnection remains unknown, but in such an active seismotectonic setting, it is possible that the river changed course following a major seismic event.

[27] Attempts to reconstruct the timing of the disconnection using mineralogical analyses of Hersek Lagoon's sediments were only partly successful, because the composition of sediments from the Yalak River and the Sea of Marmara is nearly identical. Clay minerals however provide indications about potential changes in sediment sources. In cores HK04LV5 and HK04LV6, smectite dominates $(66-70 \%)$ and is relatively stable with depth. By comparison, Yalak River sediments are enriched in smectite ( $80 \%$ at WS4 and $84 \%$ at WS7). The smectite content of Izmit Bay sediments is generally lower ( 60\%) [Yalçin and Bozkaya, 1995; Ergin et al., 1999]. Although such differences are close to the quantification limit of X-ray diffraction $( \pm 5 \%)$, these results indicate that the source of sediment did not radically change during the period covered by cores HK04LV5 and HK04LV6, and that most of the sediment originated from the Sea of Marmara. The disconnection between Yalak River and Hersek Lagoon probably happened prior to the period covered by our sediment cores.

\subsection{Late Holocene Sedimentary Processes}

[28] Since cores HK04LV5 and 6 were analyzed in details, the sedimentological interpretation is mainly based on these two cores, and extended to the whole lagoon based on the results of mascroscopical descriptions and magnetic susceptibility obtained on the eight other cores.

\subsubsection{Core HK04LV5}

[29] Most of the proxies analyzed in core HK04LV5 display an abrupt transition at $200 \mathrm{~cm}$ (Figure 4). Below $200 \mathrm{~cm}$, the sediment is characterized by high magnetic susceptibility (MS) and $\mathrm{S}$ parameter values, low sulfur concentrations, relatively high $\mathrm{C} / \mathrm{N}$ ratios, and virtual absence of aragonite, ostracods, bivalves and gastropods. At around $200 \mathrm{~cm}$ all these proxies shift dramatically. The MS values decrease by 2 orders of magnitude, the sulfur concentrations increase significantly and the $\mathrm{C} / \mathrm{N}$ ratio decreases. In addition, shells and aragonite become abundant above $155 \mathrm{~cm}$.

[30] The abrupt transition observed at $200 \mathrm{~cm}$ most likely reflects an abrupt shift from a terrestrial to an open lagoon environment. This is especially clear in the distribution of sulfur (Figure 4), which is known to be abundant in marine environments and virtually absent from most terrestrial deposits [Berner and Raiswell, 1984]. Similarly, the decrease in bulk $\mathrm{C} / \mathrm{N}$ reflects a decrease in the proportion of terrestrial versus aquatic organic matter in sediments [Meyers and Teranes, 2001], which is confirmed by the terrestrial nature of the coarse $(>500 \mu \mathrm{m})$ organic matter remains at the base of the core. The abundance of marine fauna and the decrease of the $\mathrm{S}$ parameter above $200 \mathrm{~cm}$ support this interpretation. Marine shells are particularly abundant within three coarse layers above $155 \mathrm{~cm}$, indicating a highenergy depositional environment.

[31] Below $200 \mathrm{~cm}$, the deposits are organic-rich and probably represent a wetland-type environment, with relatively low accumulation rates ( $\sim 4 \mathrm{~mm} / \mathrm{yr}$ according to the two radiocarbon dates obtained at the bottom of the core). The transition at $200 \mathrm{~cm}$ most likely represents an abrupt submergence of the lagoon (or at least its northern part), which buried the organic-rich, more terrestrial 
deposits under thick and rapidly accumulating marine sediments.

\subsubsection{Core HK04LV6}

[32] HK04LV6 sediments are subdivided into four sequences with similar lithostratigraphical, geochemical and paleoecological characteristics (Figure 5). These sequences are labeled SEQ 6.1 to 6.4 (from bottom to top), and are mostly composed of three units separated by gradual transitions. A typical sequence starts with an abrupt contact with the underlying organic-rich deposits (e.g., $295 \mathrm{~cm}$ ). The basal unit is composed of mud and generally contains abundant bivalve and gastropod shell debris, and, sometimes fining upward sand or silt layers (e.g., $220 \mathrm{~cm}$ ). This basal unit is generally overlain by foraminifera-rich mud. It is, in turn, overlain by an upper unit, which is composed of organic-rich mud relatively poor in foraminifera. These sequences are particularly well marked by continuously increasing organic matter contents (both TOC and coarse organic matter contents; Figure 5), and are interpreted as silting up, shallowing upward deposits, typical of a lagoon becoming isolated from the sea. The three abrupt transitions at 298, 232 and $107 \mathrm{~cm}$ most likely represent three major submergence events that buried dominantly terrestrial deposits under marine sediments. The lower parts of the sequences are generally coarse (shells or sand/silt layers) and therefore indicative of high-energy depositional environments.

\subsubsection{Other Cores}

[33] Although only cores HK04LV5 and 6 were analyzed in detail, some of the other cores collected in Hersek Lagoon also show a succession of opento-close lagoon deposits. Based on macroscopical descriptions, we have identified two of these sequences in core HK04LV7, at 176-83 cm (SEQ 7.1) and 83$0 \mathrm{~cm}$ (SEQ 7.2; Figure 3). SEQ 7.1 shows a typical coarse shell layer at its base and is capped by an organic-rich horizon. This horizon is overlain by SEQ 7.2 through a sharp contact that indicates a rapid burial, most likely linked to an abrupt submergence of the lagoon. The succession of deposits in core 8 seems nearly identical to core 7, although condensed. Cores 9 and 10 seem to contain the base of one sequence. Cores 1 to 4 are generally homogenous and do not show any type of depositional sequences. To facilitate the discussion, the rapid submergence events were labeled according to their stratigraphic position in each core (e.g., event 6A led to the deposition of SEQ 6.1, see Figure 5).

\subsection{Origin of the Deposits}

\subsubsection{Occurrence of Similar Sequences Along Major Subduction Zones}

[34] Sedimentary deposits similar to the sequences described above have been observed in coastal environments from major active subduction zones. These deposits have been particularly well studied in estuaries of the northeast Pacific (British Columbia, Washington, Oregon and northern California), where sequences of buried tidal marsh or peaty soils, abruptly overlain by intertidal mud are attributed to sudden submergence associated with coseismic subsidence of long stretches of coast [Atwater, 1987; Guilbault et al., 1995; Nelson et al., 1996, 2008]. These authors argue that these deposits represent great, prehistoric earthquakes (Mw 8-9) that produced repeated coseismic subsidence of 0-2 m. According to Atwater [1987], the main evidence for tectonic instability is the occurrence of couplets of thin peaty soils $(0.02-0.2 \mathrm{~m})$ representing former wetlands and thick $(0.5-1.0 \mathrm{~m})$ beds of intertidal mud. In addition, landward thinning sand sheets, occurring immediately above the peat layer in some of the sequences have been interpreted as coseismic tsunami deposits [Atwater, 1987; Guilbault et al., 1995; Nelson et al., 1996; Rhodes et al., 2006].

[35] Similar deposits have also been observed in the active subduction zones of Alaska [Shennan et al., 1999; Atwater et al., 2001; Shennan and Hamilton, 2006], New Zealand [Nichol et al., 2007] and Chile [Cisternas et al., 2005]. Observations during and after the giant earthquake of Alaska (Mw 9.2, 1964) have demonstrated that (1) sediment deposition occurs immediately upon submergence, (2) most of the postearthquake deposits accumulate in the first decade after the earthquake, and (3) $\sim 50$ years are needed to register back-to-back earthquakes [Shennan et al., 1999; Atwater et al., 2001].

[36] Based on the analysis of numerous estuaries along the Cascadia margin, Nelson et al. [1996] proposed five criteria that must be evaluated to assign a coseismic origin to rapid submergence of coastal sediments: (1) the suddenness of submergence, (2) the amount of submergence, (3) the lateral extent of submerged tidal wetland soils, (4) the coincidence of submergence with tsunamis deposits, and (5) the degree of synchronicity of 
submergence events at widely spaced sites. As indicated by Shennan et al. [1996], it is unlikely that all these criteria can be evaluated at a single site, but the probability that coastal submergence deposits are linked to a seismic origin increases with the number of criteria recognized at each site.

\subsubsection{Mechanisms Responsible for the Deposition of Hersek Sedimentary Sequences}

[37] In agreement with the results of the above mentioned studies, we argue that the sequences found in cores HK04LV5 to 7 (and to a lesser extent HK04LV8 to 10) are the signatures of major earthquakes that caused coseismic subsidence and triggered tsunamis in Izmit Bay. The sequences found in core HK04LV6, and to a certain extent cores HK04LV5 and 7, satisfy at least three of the following five criteria proposed by Nelson et al. [1996].

[38] 1. The suddenness of submergence is evidenced by abrupt organic sediment-mud contacts that are well marked in lithology and in organic matter contents. The occurrence of in situ marsh plant remains within the organic-rich layers provides additional evidence of rapid burial.

[39] 2. The presence of coarse shell or sand layers at the base of each sequence is a clear indicator of the co-occurrence of a tsunami. Shell deposits preserved in cores HK04LV5 and 6 are mainly composed of marine species that thrive at shallow depths in the Sea of Marmara [Eryilmaz et al., 1995], and the mixed assemblages of highly fragmented and articulated specimens are typical for tsunami deposits according to the criteria of Donato et al. [2008] (extensive angular fragmentation and presence of allochtonous articulated bivalves). The shells most likely originate from the shallow shellrich sandy deposits that occur at 0-10 $\mathrm{m}$ depth along Hersek Peninsula [Eryilmaz et al., 1995] (Figure 1). Their transport into the lagoon by tsunami waves was probably facilitated by submergence and/or breaching of the coastal barrier. A storm origin of the shell layers is unlikely since (1) they are restricted to the base of coseismic sequences (storm deposits would occur throughout the cores), and (2) they contain a mixture of marine, lagoonal and nonmarine ostracod shells [Mischke et al., 2011]. All the sequences described in core 6 contain basal shell deposits, except for SEQ 6.3, which has fining upward silt and sand layers, similar to the tsunami deposits described in estuaries from the Cascadia Margin [Guilbault et al., 1995]. This difference likely reflects (1) the coring location in front of the sandbarrier and (2) a possible delay between the tsunami and the subsidence event at Hersek.

[40] 3. A considerable amount of submergence is reflected in the systematic increases in foraminifera concentration above the tsunami deposits, and by the co-occurrence of maxima in foraminifera diversity, which demonstrate an open-marine influence in the lagoon. These characteristics seem to indicate a sudden submergence of the coastal barrier, most likely in relation with rapid subsidence, temporarily increasing the exchanges of benthos and sediment between the Sea of Marmara and the lagoon, as observed in British Columbia [Guilbault et al., 1996]. The single occurrence of Gyroidines in SEQ 6.3 (Figure 6) points to exceptional submergence of the lagoon by seawater previously mixed by the tsunami wave(s), since Gyroidines is commonly found in open seas at depths of 16-80 m [Murray, 1991].

[41] The evaluation of the last two criteria of Nelson et al. [1996] (extension of the peat-mud couplets and synchronicity of submergence) is less easily applicable to our data since they require observation of continuous sections across the lagoon, a higher density of cores, and a very large number of radiocarbon dates, none of which is available in the framework of this exploratory study. Subsurface profiling would also help in confirming the lateral continuity, and therefore coseismic origin of the deposits.

\subsection{Chronology}

\subsubsection{Radiocarbon Dating}

[42] Since the organic-rich layers that constitute the upper parts of the coseismic subsidence sequences represent marsh soils that were rapidly submerged by postseismic deposits, dating these layers provides an accurate estimate of the age of the event that triggered their burial. Following this principle, all of the marsh soils in cores HK04LV5, 6 and 7 were radiocarbon dated (Table 2 and Figure 7), with samples preferentially taken in the upper part of the organic-rich layers.

[43] As shown in Figure 7, core HK04LV5, the only core collected north of the fault trace (Figure 2), has recorded a single event (event 5A) that is dated at 664-898 A.D. The two dates obtained on organic macroremains incorporated in the overlying postseismic deposit are statistically indiscernible from the age of the event, providing evidence 
Table 2. Radiocarbon Ages Obtained on Marsh Plant Remains From Cores HK04LV5, HK04LV6, and HK04LV7 ${ }^{\mathrm{a}}$

\begin{tabular}{lccccc}
\hline $\begin{array}{c}\text { Coring } \\
\text { Site }\end{array}$ & $\begin{array}{c}\text { Composite } \\
\text { Depth }(\mathrm{cm})\end{array}$ & $\begin{array}{c}\text { Lab } \\
\text { Accession } \\
\text { Number }\end{array}$ & $\begin{array}{c}\text { Radiocarbon } \\
\text { Age } \pm 1 \sigma \\
\text { (year B.P.) }\end{array}$ & $\begin{array}{c}\text { Calibrated Ages With } \\
\text { 2 } \sigma \text { Error Range } \\
\text { (year A.D.) }\end{array}$ & $\begin{array}{c}\text { Weighted Average } \\
\text { (year A.D.) }\end{array}$ \\
\hline HK04LV5 & $40-45$ & Poz-14522 & $1235 \pm 35$ & $686-881(95.4 \%)$ & 777 \\
HK04LV5 & $97.5-102.5$ & Poz-12826 & $1190 \pm 30$ & $769-898(88.8 \%)$ & 834 \\
HK04LV5 & $210-215$ & Poz-12827 & $1230 \pm 60$ & $664-898(92.1 \%)$ & 792 \\
HK04LV5 & $329-334$ & Poz-12825 & $1590 \pm 80$ & $320-623(91.3 \%)$ & 511 \\
HK04LV6 & $113.5-118.5$ & Poz-12828 & $460 \pm 30$ & $1412-1469(95.4 \%)$ & 1438 \\
HK04LV6 & $242.5-247.5$ & Poz-16606 & $400 \pm 50$ & $1428-1635(95.4 \%)$ & 1501 \\
HK04LV6 & $301-306$ & Poz-12786 & $1035 \pm 30$ & $949-1036(89.7 \%)$ & 1001 \\
HK04LV7 & $94-98$ & Poz-16607 & $205 \pm 30$ & $1646-1955(95.4 \%)$ & 1742 \\
HK04LV7 & $142-147$ & Poz-16608 & $170 \pm 30$ & $1659-1954(95.4 \%)$ & 1746 \\
\hline
\end{tabular}

${ }^{a}$ No sample had F14C $>1$. The results were calibrated with Oxcal 3.9 [Bronk Ramsey, 2001] using the IntCal04 calibration curve [Reimer et al., 2004].

that SEQ 5.1 accumulated extremely rapidly after the coseismic subsidence (Figure 4). The three shell deposits that occur in the upper half of the core most likely represent three distinct tsunami waves, in-between which silt material accumulated rap- idly. By comparison, the date obtained at the bottom of the core shows that the underlying marsh soil, also about $200 \mathrm{~cm}$ thick, took over 300 year to accumulate, at an average rate of $\sim 4 \mathrm{~mm} / \mathrm{yr}$.

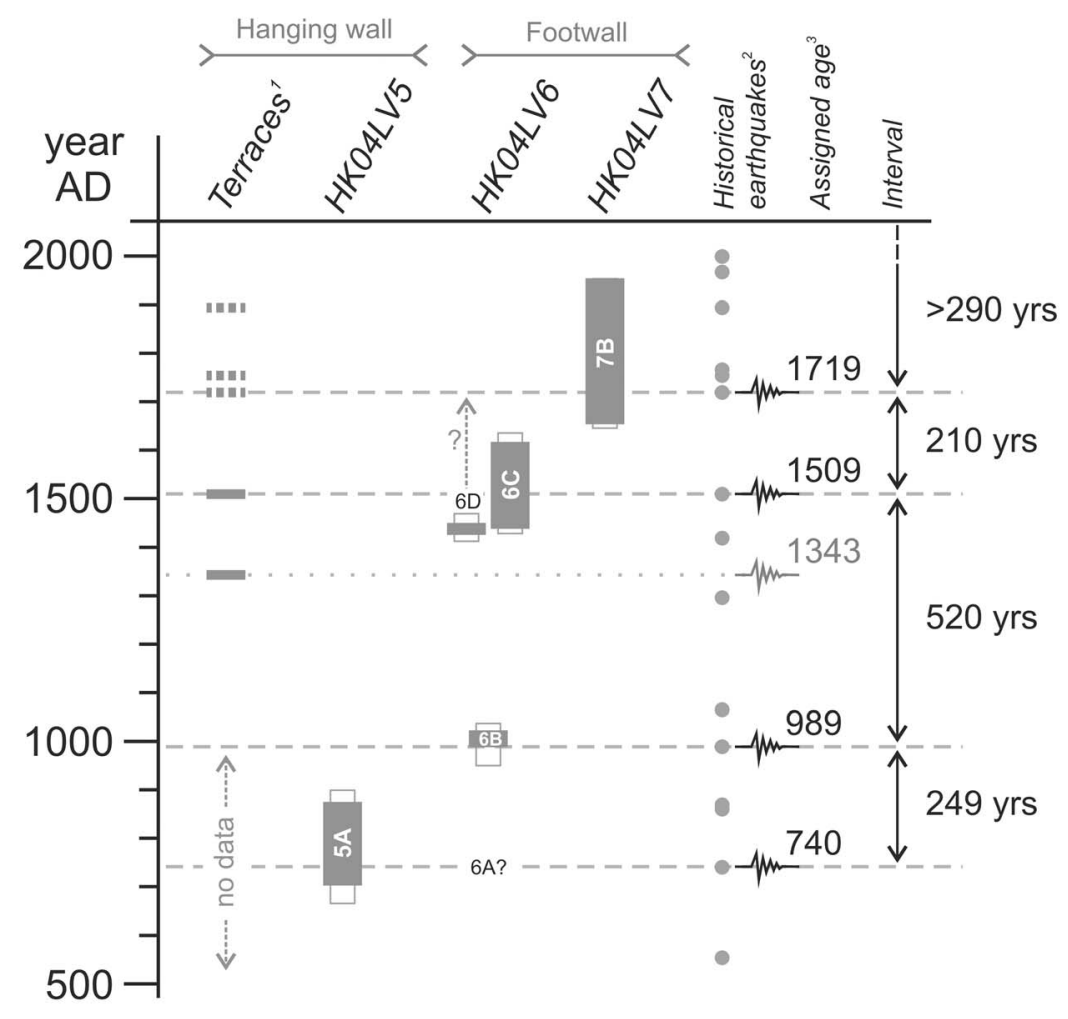

Figure 7. Chronology of the seismic events recorded in the deposits (terraces) of Hersek ridge [Özaksoy et al., 2010] and in sediment cores HK04LV5, 6, and 7 (our results). The gray and open boxes represent 1- and 2-sigma intervals of the ${ }^{14} \mathrm{C}$ calibrated ages, respectively. The dashed arrow indicates alternative age hypothesis for event $6 \mathrm{D}$ (see section 5.4). Footnote 1: from Özaksoy et al. [2010]. Footnote 2: historical earthquakes with Ms $\geq 6.8$ and with an estimated epicenter located within a $100 \mathrm{~km}$ radius from Hersek (from Ambraseys [2002]). Footnote 3: ages assigned according to criteria explained in section 5.4. The ages assigned to the four events recorded in Hersek Lagoon sediment all occur within the 1-sigma interval of their calibrated radiocarbon ages. 
[44] The three youngest events recorded in core HK04LV6 (Figures 5 and 7) are dated at 9491036 A.D. (6B), 1428-1635 A.D. (6C) and 14121469 A.D. (6D). Although a fourth sequence is recorded at the base of the core (SEQ 6.1), the age of the responsible event (6A) is unknown because the core did not reach the underlying organic-rich deposit. The age of event $6 \mathrm{C}$, which is characterized by an exceptional amount of submergence (see previous paragraph), is statistically indiscernible from the age of event 6D. However, these two events must be separated by a significant amount of time since at least 50 years are needed to register back-to-back earthquakes [Atwater et al., 2001]. This duration was likely higher because the marsh soil that underlies event $6 \mathrm{D}$ at $105-125 \mathrm{~cm}$ is relatively well developed.

[45] Core HK04LV7 has recorded two events (Figures 3 and 7). The younger one (7B) is dated at $1646-1955$ A.D., an interval of multiple ${ }^{14} \mathrm{C}$ plateaus which precludes exact age determination by radiocarbon methods [Reimer et al., 2004]. The event is younger than any recorded in core HK04LV6, except if the real age of event 6D is significantly younger than $\sim 1500$ A.D. (i.e., the plant remain used to date even $6 \mathrm{D}$ died before burial of the marsh soil). In this case, event 6D might correspond to event $7 \mathrm{~B}$. The absence of tsunami deposits associated with both events (6D and 7B, Figure 3) supports this interpretation.

[46] The chronological results obtained on cores HK04LV5, 6 and 7 are summarized in Figure 7, which shows that the cored sediments have recorded a total of four, possibly five, seismic events during the last 1200 years. It is remarkable that site HK04LV5 has not recorded any seismic event after (i.e., younger than) event 5A (664898 A.D.), which demonstrates that most subsidence events are restricted to the main lagoon, i.e., south of the fault trace. Event 5A most likely represents a gravitational collapse of the hanging wall during a noncharacteristic earthquake. It is very likely that some of the events observed in cores HK04LV6 and 7 have been recorded elsewhere in the southern part of the lagoon, but a denser coring grid is needed to confirm this assumption.

\subsubsection{Comparison With Historical Records}

[47] Fifty-five large (estimated $\mathrm{Ms} \geq 6.8$ ) earthquakes seem to have affected the Sea of Marmara region during the last 2000 years [Ambraseys, 2002]. Here, we excluded events located outside a $100 \mathrm{~km}$ radius from Hersek using the estimated epicenter locations of Ambraseys [2002]. This first selection criterion reduced the number of large earthquakes to 27 , among which only 15 occurred after 500 A.D. (Figure 7). The historical earthquakes occurring within the 2 sigma error range of the radiocarbon age of each Hersek event were then examined to determine the most probable age of each event, using specific information such as the estimated location of the affected region and the presence/absence of associated tsunami.

[48] Event 5A (664-898 A.D.) is only recorded in core HK04LV5, i.e., north of the fault trace. Three major historical earthquakes occur within this age range: at 740, 860 and 869 [Ambraseys, 2002]. No tsunamis are associated with the weaker 860 and 869 earthquakes [Ambraseys and Finkel, 1991; Altinok and Ersoy, 2000; Ambraseys, 2002] so it is very likely that event $5 \mathrm{~A}$ represents the 740 earthquake (estimated Ms 7.1), which was accompanied by a tsunami that affected Istanbul and Izmit [Altinok and Ersoy, 2000; Yalçiner et al., 2002].

[49] Event 6B is well marked in core HK04LV6. Its radiocarbon age (949-1036 A.D.) matches remarkably well the 989 earthquake. The only other earthquake corresponding to this age range occurred in 967 A.D. but its estimated epicenter is located $170 \mathrm{~km}$ east of Hersek and it has no associated tsunami [Ambraseys, 2002]. Hence, event 6B most likely represents the destructive Ms 7.2, 989 earthquake, which epicenter is believed to be located in the eastern part of the Sea of Marmara at approximately $70 \mathrm{~km}$ west of Hersek [Ambraseys, 2002; Yalçiner et al., 2002].

[50] Event 6C is the largest event recorded in Hersek Lagoon sediments south of fault trace. It has a radiocarbon age of 1428-1635 A.D. The only corresponding major historical earthquake is the well-documented 1509 event that caused heavy damages in Istanbul and was followed by a tsunami in the eastern part of the Sea of Marmara [Ambraseys and Finkel, 1990, 1991; Altinok and Ersoy, 2000; Ambraseys and Jackson, 2000; Ambraseys, 2001, 2002]. Historical documents do not mention damages in Izmit Bay [Ambraseys, 2001], except for the destruction of Hersek Mosque in 1509 [Witter et al., 2000]. Its epicenter is believed to be located in the Sea of Marmara, immediately south of Istanbul [Ambraseys and Jackson, 2000; Ambraseys, 2001, 2002]. Most of these characteristics are in agreement with the sedimentological description of event $6 \mathrm{C}$, and we therefore feel confident to assign an age of 1509 A.D. to this event. 
[51] Event 7B is the most recent event recorded in Hersek Lagoon sediments. It is radiocarbon dated at 1646-1955 A.D. and has no clear associated tsunami deposit, similarly to event $6 \mathrm{D}$, which may be coeval (see above, Figure 3). Historical data indicate that four major earthquakes occurred within this time range $(1719,1754,1766$ and 1894) [Ambraseys, 2002]. The well-defined epicenter locations of these four events are all located within less than $50 \mathrm{~km}$ from Hersek [Ambraseys, 2002]. The major difference between these events is the absence of tsunami associated with the 1719 earthquake, likely due to the onshore location of most of the rupture zone [Altinok and Ersoy, 2000; Ambraseys and Jackson, 2000; Ambraseys, 2002]. It is also the earthquake with the highest estimated surface magnitude (Ms 7.4) [Ambraseys, 2002]. Since no clear tsunami deposit is associated with event 7B in the sedimentary record, we associate this event with the 1719 earthquake. The 1719 earthquake is known to have destroyed or badly damaged most of the towns located on the coasts of Izmit Bay from Yalova to Duzce, including Karamürsel [Ambraseys and Finkel, 1991].

\section{Discussion}

\subsection{Amount of Subsidence}

[52] Although no transfer function is available to quantify the amount of subsidence of each of the events recorded in Hersek Lagoon, the importance of the vertical deformations can be estimated using the thickness of the sedimentary sequences. This follows the findings of Atwater et al. [2001], who demonstrated that the thickness of the sedimentary sequences related to the 1964 Alaska earthquake faithfully reflects the amount of vertical deformation, and that background sedimentation is negligible. The important thickness of the Hersek sequences $(60-200 \mathrm{~cm})$, compared to the postseismic Cascadia deposits (generally $50-100 \mathrm{~cm}$ ) therefore indicates particularly high amounts of subsidence, representing vertical deformations of $60 \mathrm{~cm}$ (event 6B) to $200 \mathrm{~cm}$ (event 5A). Following this principle, we estimate that the vertical deformations associated to the 1509 and 1719 earthquakes are in the order of $120 \mathrm{~cm}$, and that the 740 earthquake caused the $200 \mathrm{~cm}$ subsidence of the northernmost side of the lagoon. By contrast, the relative thinness of SEQ $6.2(60 \mathrm{~cm})$, which represents the 989 earthquake, may indicate a lower amount of coseismic subsidence. In addition, we believe that only major vertical deformations
$(>50 \mathrm{~cm})$ are recorded in Hersek Lagoon since the accommodation space created by minor events is not important enough to be filled by sediment before disappearing via postseismic rebound. This would explain why the $\sim 20 \mathrm{~cm}$ coseismic subsidence that affected Hersek Lagoon after the 1999 Izmit earthquake was not recorded.

\subsection{Late Holocene Activity of the NNAF in Izmit Bay}

[53] Paleoseismological reconstructions around Izmit Bay, and in the Sea of Marmara region in general, are relatively rare. Our data indicate that 4 major earthquakes caused coseismic subsidence on Hersek Peninsula during the last 1500 years. The latest collapse of the northernmost side of Hersek Lagoon, i.e., the hanging wall, occurred during the 740 earthquake. The main lagoon (i.e., the footwall, south of the fault trace) subsided during the 989, 1509 and 1719 earthquakes (Figure 7).

[54] The collapse of the hanging wall in 740 A.D. is atypical for Hersek Peninsula. Indeed, the data of Özaksoy et al. [2010] suggest that Hersek hill, i.e., the hanging wall, was tectonically uplifted by the 1343-1344 and 1509 earthquakes, and by some of the seismic events dated at 1719 A.D., 1754 A.D. and 1894 A.D. (Figure 7). Their data also show that the ridge subsided at least once, between 1350 and 1500 A.D. Unfortunately, their record lacks data between 500 and 1000 A.D., because of erosion of the contemporary marine terraces. Interestingly, the single episode of subsidence recorded in Hersek core HK04LV5 corresponds to this period, which suggests that most of the hanging wall collapsed during the 740 earthquake, explaining the erosion of the marine deposits at the tip of Hersek Peninsula.

[55] The subsidence events of 989, 1509 and 1719 A.D. are more typical for the area, since they represent a downward movement of the footwall, which is expected for a reverse fault. Our data suggests that the coseismic subsidence of Hersek Lagoon during the 989 earthquake was accompanied by a tsunami. This observation is in good agreement with the results of Özaksoy et al. [2010], who identified sand and shells deposits related to the 989 event on Hersek Peninsula. The marine records of McHugh et al. [2006] in Izmit Bay do not contain sediments deposited between $\sim 900$ and $\sim 1450$ A.D.

[56] According to our results, the 1509 earthquake was characterized by $\sim 1.2 \mathrm{~m}$ of subsidence and by 
a considerable amount of submergence. It also seems that the marine terraces of Hersek ridge (i.e., north of the fault trace) were uplifted by the 1509 earthquake, which means that both the hanging wall and the footwall moved during the earthquake. Further east in Izmit Bay, about $25 \mathrm{~km}$ from Hersek near Gölcük, Klinger et al. [2003] identified two buried colluvial wedges related to paleoscarps from the 1509 and 1719 earthquakes. In addition, McHugh et al. [2006] found sedimentary indications of mass-wasting events associated with the 1509 earthquakes on the western, submarine slope of Hersek Peninsula. Fossil-rich mass flow deposits most likely related to the 1509 earthquake were also described in a sediment core collected several $\mathrm{km}$ west of Hersek in the Sea of Marmara [Çagatay et al., 2003]. All these characteristics display the exceptional magnitude and extension of the rupture zone of the 1509 event.

[57] The most recent event recorded in Hersek sediment cores is the 1719 earthquake. The subsidence of Hersek Lagoon during this event was of the same order of magnitude than during the 1509 earthquake. Although Özaksoy et al. [2010] did not clearly identify the 1719 earthquake in the marine terraces of Hersek ridge, these authors indicate minor terrace uplift during one of the seismic events in 1719,1754 or 1894 A.D. If the later occurred in 1719 A.D., this would suggest the co-occurrence of subsidence of the footwall and uplift of the hanging wall, as for the 1509 earthquake. At Gölcük, the second colluvial wedge related to paleoscarps was also linked to the 1719 earthquake [Klinger et al., 2003]. McHugh et al. [2006] do not describe any event deposit associated to the 1719 earthquake, but their record contains sedimentary indications of submarine mass-wasting events associated to the 1766 earthquake. This interpretation is however based on a complex core stratigraphy interpreted as mixing and reworking of one masswasting deposit by two distinct seismic events, and is therefore questionable. It is anyway not possible to differentiate the 1719 and 1766 based on radiocarbon data only.

[58] From these data, it appears that vertical deformation occurred simultaneously at Hersek and Gölcük during the 1509 and 1719 earthquakes, indicating that the fault rupture stepped across the Karamürsel basin during both events. Our results therefore confirm the observations made during recent high-resolution bathymetrical surveys [Cormier et al., 2006], which demonstrate that the NNAF in Izmit Bay is more continuous than thought by former studies [e.g., Barka et al., 2002; Lettis et al., 2002].
They also suggest that the amount of subsidence of Hersek Lagoon (south of the bend) is of the same order of magnitude than the amount of uplift of Hersek pressure ridge $(3.5 \mathrm{~m} / \mathrm{kyr}$ [Özaksoy et al., 2010]).

\section{Conclusions}

[59] The sediments deposited in Hersek coastal lagoon were successfully used to reconstruct past subsidence associated with Hersek restraining bend. Although coastal sediments are well-known for recording coseismic subsidence in subduction zone areas, we demonstrate that they can also be used to reconstruct past earthquakes in transform plate boundary settings. In Hersek Lagoon, coseismic subsidence creates sedimentary sequences composed of a basal coarse (shells or sand/silt) tsunami layer, followed by a thick mud unit capped by an organic-rich horizon. These sequences resemble the coseismic peat-mud couplets of the Cascadia margin, and represent the vertical deformations that occur at Hersek restraining bend during major earthquakes. The Hersek paleoseismological record shows that coastal deformation is accommodated in 60-200 cm subsidence events during major earthquakes, which maintain the status of Hersek coastal lagoon and delay its final infill. Four events were recorded during the last 1000-1500 years. The ages of these events were estimated by comparing radiocarbon results to historical chronicles, which indicate (1) the atypical collapse of the hanging wall during the 740 earthquake and (2) subsidence of the footwall during the 987, 1509 and 1719 earthquakes. Our results also suggest the co-occurrence of subsidence of the footwall and uplift of the hanging wall during the 1509 and 1719 earthquakes, and they confirm that the step-over model of Barka et al. [2002] and Lettis et al. [2002] is not valid for the Karamürsel basin.

\section{Acknowledgments}

[60] This research was funded by the European Union in the framework of the REL.I.E.F. (Reliable Information on Earthquake Faulting) project (EVG1-CT-2002-00069). We would like to acknowledge Pedro Costa (Brunel University), Salim Öncel (Gebze Institute of Technology), Özden Ileri, and Fatih Uyssal (Ankara University) for assistance during our fieldwork expeditions in Turkey. We are grateful to Lina Mehta, Vanessa Tomasz, and Paul Szadorsky (Brunel University) for laboratory assistance. Andrea Lini (University of Vermont) performed the TOC and TN analyses. We thank Nathalie Fagel (University of Liège, Belgium) and Helge Arz (GFZ, Potsdam, 
Germany) for providing access to the X-ray diffraction and GEOTEK multisensor core logging facilities, respectively. This paper has benefited from the detailed and constructive review provided by James Dolan. Comments from two anonymous reviewers led to additional improvements. During the writing of this article, S.B. was an EU Marie Curie postdoctoral fellow at AWI, Germany and a FWO postdoctoral fellow at UGent, Belgium.

\section{References}

Alpar, B., and A. Güneysu (1999), Evolution of the Hersek Delta (İzmit Bay), Turk. J. Mar. Sci., 5, 57-74.

Altinok, Y., and Ș. Ersoy (2000), Tsunamis observed on and near Turkish coast, Nat. Hazards, 21(2-3), 185-205, doi:10.1023/A:1008155117243.

Altinok, Y., S. Tinti, B. Alpar, A. C. Yalçıner, Ș. Ersoy, E. Bortolucci, and A. Armigliato (2001), The tsunami of August 17, 1999 in İzmit Bay, Turkey, Nat. Hazards, 24, 133-146, doi:10.1023/A:1011863610289.

Ambraseys, N. (2001), The earthquake of 1509 in the Sea of Marmara, Turkey, revisited, Bull. Seismol. Soc. Am., 91(6), 1397-1416, doi:10.1785/0120000305.

Ambraseys, N. (2002), The seismic activity of the Marmara Sea region over the last 2000 years, Bull. Seismol. Soc. Am., 92(1), 1-18, doi:10.1785/0120000843.

Ambraseys, N., and C. Finkel (1990), The Marmara Sea earthquake of 1509, Terra Nova, 2, 167-174, doi:10.1111/j.13653121.1990.tb00059.x.

Ambraseys, N., and C. Finkel (1991), Long-term seismicity of Istanbul and of the Marmara Sea region, Terra Nova, 3, 527539, doi:10.1111/j.1365-3121.1991.tb00188.x.

Ambraseys, N., and J. A. Jackson (2000), Seismicity of the Sea of Marmara (Turkey) since 1500, Geophys. J. Int., 141, F1-F6, doi:10.1046/j.1365-246x.2000.00137.x.

Armijo, R., B. Meyer, S. Navarro, G. King, and A. Barka (2002), Assymetric slip partitioning in the Sea of Marmara pull-apart: A clue to propagation processes of the North Anatolian Fault?, Terra Nova, 14, 80-86, doi:10.1046/ j.1365-3121.2002.00397.x.

Atwater, B. (1987), Evidence for great Holocene earthquakes along the outer coast of Washington State, Science, 236, 942-944, doi:10.1126/science.236.4804.942.

Atwater, B., D. Yamaguchi, S. Bondevik, W. Barnhardt, L. Amidon, B. Benson, G. Skjerdal, J. Shulene, and F. Nanayama (2001), Rapid resetting of an estuarine recorder of the 1964 Alaska Earthquake, Geol. Soc. Am. Bull., 113, 1193-1204, doi:10.1130/0016-7606(2001)113<1193: RROAER $>2.0 . \mathrm{CO} ; 2$.

Barka, A. (1996), Slip distribution along the North Anatolian fault associated with the large earthquakes of the period 1939 to 1967, Bull. Seismol. Soc. Am., 86(5), 1238-1254.

Barka, A. (1999), 17 August 1999 Izmit earthquake, Science, 285, 1858-1859, doi:10.1126/science.285.5435.1858.

Barka, A., and C. Kadinsky-Cade (1988), Strike-slip fault geometry in Turkey and its influence on earthquake activity, Tectonics, 7, 663-684, doi:10.1029/TC007i003p00663.

Barka, A., et al. (2002), The surface rupture and slip distribution of the 17 August 1999 Izmit earthquake (M 7.4), North Anatolian Fault, Bull. Seismol. Soc. Am., 92, 43-60, doi:10.1785/0120000841.

Berner, R., and R. Raiswell (1984), C/S method for distinguishing freshwater from marine sedimentary rocks, Geology, 12,
365-368, doi:10.1130/0091-7613(1984)12<365:CMFDFF $>$ 2.0.CO;2.

Bird, E. (1994), Physical setting and geomorphology of coastal lagoons, in Coastal Lagoon Processes, edited by B. Kjerfve, pp. 9-39, Elsevier, Amsterdam, doi:10.1016/S0422-9894 (08)70007-2.

Bondevik, S., J. Svendsen, G. Johnsen, J. Mangerud, and P. Kaland (1997), The Storegga tsunami along the Norwegian coast, its age and runup, Boreas, 26, 29-53, doi:10.1111/ j.1502-3885.1997.tb00649.x.

Bronk Ramsey, C. (2001), Development of the radiocarbon program OxCal, Radiocarbon, 43(2A), 355-363.

Çagatay, N., N. Görür, A. Polonia, E. Demirbag, M. Sakınç, M.-H. Cormier, L. Copotondi, C. McHugh, Ö. Emre, and K. Eriş (2003), Sea-level changes and depositional environments in the İzmit Gulf, eastern Marmara Sea, during the late glacial-Holocene period, Mar. Geol., 202, 159-173, doi:10.1016/S0025-3227(03)00259-7.

Cisternas, M., et al. (2005), Predecessors of the giant 1960 Chile earthquake, Nature, 437(7057), 404-407, doi:10.1038/nature03943.

Cormier, M.-H., et al. (2006), The North Anatolian fault in the Gulf of Izmit (Turkey): Rapid vertical motion in response to minor bends of a non-vertical continental transform, J. Geophys. Res., 111, B04102, doi:10.1029/2005JB003633.

Donato, S., E. Reinhardt, J. Boyce, R. Rothaus, and T. Vosmer (2008), Identifying tsunami deposits using bivalve shell taphonomy, Geology, 36(3), 199-202, doi:10.1130/ G24554A.1.

Ergin, M., S. Kapur, Z. Karaka, E. Akca, Ö. Kangal, and S. Keskin (1999), Grain size and clay mineralogy of late Quaternary sediments on a tectonically active shelf, the southern Sea of Marmara: Clues to hydrographic, tectonic and climatic evolution, Geol. J., 34(1-2), 199-210, doi:10.1002/(SICI)1099-1034(199901/06)34:1/2<199::AIDGJ821>3.0.CO;2-9.

Eryilmaz, M., F. Yücesoy-Eryilmaz, Z. Kirca, and E. Dogan (1995), Distribution of sediments in the Gulf of Izmit and influencing factors, in Quaternary Sequence in the Gulf of Izmit, edited by E. Meric, pp. 269-276, Turk. Navy Press, Istanbul, Turkey.

Fujiwara, O., F. Masuda, T. Sakai, T. Irizuki, and K. Fuse (2000), Tsunami deposits in Holocene bay mud in southern Kanto region, Pacific coast of central Japan, Sediment. Geol., 135, 219-230, doi:10.1016/S0037-0738(00)00073-7.

Guilbault, J.-P., J.-J. Clague, and M. Lapointe (1995), Amount of subsidence during a late Holocene earthquake-Evidence from fossil tidal marsh foraminifera at Vancouver Island, west coast of Canada, Palaeogeogr. Palaeoclimatol. Palaeoecol., 118, 49-71, doi:10.1016/0031-0182(94)00135-U.

Guilbault, J.-P., J.-J. Clague, and M. Lapointe (1996), Foraminiferal evidence for the amount of coseismic subsidence during a late Holocene earthquake on Vancouver Island, west coast of Canada, Quat. Sci. Rev., 15, 913-937, doi:10.1016/ S0277-3791(96)00058-3.

Hayward, B., H. Grenfell, A. Sabaa, R. Carter, U. Cochran, J. Lipps, P. Shane, and M. Morley (2006), Micropaleontological evidence of large earthquakes in the past 7200 years in southern Hawke's Bay, New Zealand, Quat. Sci. Rev., 25, 1186-1207, doi:10.1016/j.quascirev.2005.10.013.

Hergert, T., and O. Heidbach (2010), Slip-rate variability and distributed deformation in the Marmara Sea fault system, Nat. Geosci., 3, 132-135, doi:10.1038/ngeo739.

Hubert-Ferrari, A., A. Barka, E. Jacques, S. Nalbant, B. Meyer, R. Armijo, P. Tapponnier, and G. King (2000), Seismic haz- 
ard in the Sea of Marmara following the Izmit Earthquake, Nature, 404, 269-273, doi:10.1038/35005054.

Kelsey, H., A. Nelson, E. Hemphill-Haley, and R. Witter (2005), Tsunami history of an Oregon coastal lake reveals a $4600 \mathrm{yr}$ record of great earthquakes on the Cascadia subduction zone, Geol. Soc. Am. Bull., 117, 1009-1032, doi:10.1130/B25452.1.

Klinger, Y., K. Sieh, E. Altunel, A. Akoglu, A. Barka, T. Dawson, T. Gonzalez, A. Meltzner, and T. Rockwell (2003), Paleoseismic evidence of characteristic slip on the western segment of the North Anatolian Fault, Turkey, Bull. Seismol. Soc. Am., 93, 2317-2332, doi:10.1785/0120010270.

Kozaci, Ö. (2002), Hersek deltasi'nda kuzey anadolu fayi'nin Yalova segmenti üzerinde paleosismolojik calismalar, MSc thesis, Istanbul Tech. Univ., Istanbul, Turkey.

Kozaci, Ö., E. Altunel, S. Lindvall, C. Brankman, and W. Lettis (2011), The North Anatolian Fault on Hersek Peninsula, Turkey: Its geometry and implications on the 1999 Izmit earthquake rupture propagation, Turk. J. Earth Sci., doi:10.3906/yer-0910-45, in press.

Ku, H., Y. Chen, C. Hsieh, T. Liu, and J. C. Liu (2001), Paleoenvironment study at Yihju, southwestern Taiwan: A case on geochemical analysis of sulfur and carbon, West. Pac. Earth Sci., 1(2), 175-186.

Kuşçu, I., M. Okamura, H. Matsuoka, and Y. Awata (2002), Active faults on Izmit on the North Anatolian Fault, NW Turkey: A high-resolution shallow seismic study, Mar. Geol., 190, 421-443, doi:10.1016/S0025-3227(02)00357-2.

Lettis, W., J. Bachluber, R. Witter, C. Brankman, C. E. Randolph, A. Barka, W. D. Page, and A. Kaya (2002), Influence of releasing step-overs on surface fault rupture and fault segmentation: Examples from the 17August 1999 Izmit earthquake on the North Anatolian Fault, Turkey, Bull. Seismol. Soc. Am., 92(1), 19-42, doi:10.1785/0120000808.

McClusky, S., et al. (2000), Global positioning system constraints on plate kinematics and dynamics in the eastern Mediterranean and Caucasus, J. Geophys. Res., 105(B3), 5695-5720, doi:10.1029/1999JB900351.

McHugh, C., L. Seeber, M.-H. Cormier, J. Dutton, N. Çagatay, A. Polonia, W. Ryan, and N. Görür (2006), Submarine earthquake geology along the North Anatolian Fault in the Marmara Sea, Turkey: A model for transform basin sedimentation, Earth Planet. Sci. Lett., 248, 661-684, doi:10.1016/j.eps1.2006.05.038.

Meyers, P. A., and J. L. Teranes (2001), Sediment organic matter, in Tracking Environmental Changes Using Lake Sediment, vol. 2, Physical and Geochemical Methods, edited by W. M. Last, and J. P. Smol, pp. 239-269, Kluwer Acad., Dordrecht, Netherlands.

Mischke, S., U. Schudack, S. Bertrand, and S. Leroy (2011), Ostracods from a Marmara Sea lagoon (Turkey) as tsunami indicators, Quaternary Int., doi:10.1016/j.quaint.2010. 11.013 , in press.

Murray, J. (1991), Ecology and Palaeoecology of Benthic Foraminifera, Longman, Essex, U. K.

Nelson, A., I. Shennan, and A. Long (1996), Identifying coseismic subsidence in tidal-wetland Stratigraphical sequences at the Cascadia subduction zone of western North America, J. Geophys. Res., 101(B3), 6115-6135, doi:10.1029/95JB01051.

Nelson, A., Y. Sawai, A. Jennings, L.-A. Bradley, L. Gerson, B. Sherrod, J. Sabean, and B. Horton (2008), Greatearthquake paleogeodesy and tsunamis of the past 2000 years at Alsea Bay, central Oregon coast, USA, Quat. Sci. Rev., 27(7-8), 747-768, doi:10.1016/j.quascirev.2008.01.001

Nichol, S., O. Lian, M. Horrocks, and J. Goff (2007), Holocene record of gradual, catastrophic, and human-influences sedimentation from a backbarrier wetland, northern New Zealand, J. Coastal Res., 233, 605-617, doi:10.2112/040185.1.

Özaksoy, V., Ö. Emre, C. Yildirim, A. Doğan, S. Özalp, and F. Tokay (2010), Sedimentary record of late Holocene seismicity and uplift of Hersek restraining bend along the North Anatolian Fault in the Gulf of Izmit, Tectonophysics, 487, 33-45, doi:10.1016/j.tecto.2010.03.006.

Pinegina, T., J. Bourgeois, L. Bazanova, I. Melekestsev, and O. Braitseva (2003), A millennial-scale record of Holocene tsunamis on the Kronotskiy Bay coast, Kamchatka, Russia, Quat. Res., 59, 36-47, doi:10.1016/S0033-5894(02)00009-1.

Rathje, E., I. Karatas, S. Wright, and J. Bachhuber (2004), Coastal failures during the 1999 Kocaeli earthquake in Turkey, Soil. Dyn. Earthquake Eng., 24(9-10), 699-712, doi:10.1016/j.soildyn.2004.06.003.

Reimer, P., et al. (2004), IntCal04 Terrestrial radiocarbon age calibration, 0-26 cal kyr BP, Radiocarbon, 46(3), 1029-1058.

Rhodes, B., M. Tuttle, B. Horton, L. Doner, H. Kelsey, A. Nelson, and M. Cisternas (2006), Paleotsunami research, Eos Trans. $A G U, 87(21), 205-209$, doi:10.1029/2006EO210002.

Shennan, I., and S. Hamilton (2006), Coseismic and preseismic subsidence associated with great earthquakes in Alaska, Quat. Sci. Rev., 25(1-2), 1-8, doi:10.1016/j.quascirev. 2005.09.002.

Shennan, I., A. Long, M. Rutherford, F. Green, J. Innes, J. Lloyd, Y. Zong, and K. Walker (1996), Tidal marsh stratigraphy, sea-level change and large earthquakes, I: A 5000 year record in Washington, USA, Quat. Sci. Rev., 15, 1023-1059, doi:10.1016/S0277-3791(96)00007-8.

Shennan, I., D. Scott, M. Rutherford, and Y. Zong (1999), Microfossil analysis of sediments representing the 1964 earthquake, exposed at Girdwood Flats, Alaska, USA, Quat. Int., 60, 55-73, doi:10.1016/S1040-6182(99)00007-5.

Tinti, S., A. Armigliato, A. Manucci, G. Pagnoni, F. Zaniboni, A. C. Yalciner, and Y. Altinok (2006), The generating mechanisms of the August 17, 1999 Izmit bay (Turkey) tsunami: Regional (tectonic) and local (mass instabilities) causes, Mar. Geol., 225(1-4), 311-330, doi:10.1016/j.margeo. 2005.09.010.

Witter, R., W. Lettis, J. Bachhuber, A. Barka, E. Evren, Z. Cakir, D. Page, J. Hengesh, and G. Seitz (2000), Paleoseismic trenching study across the Yalova segment of the North Anatolian fault, Hersek Peninsula, Turkey, in The 1999 Izmit and Düzce Earthquakes: Preliminary Results, edited by A. Barka et al., pp. 329-339, Istanbul Tech. Univ., Istanbul, Turkey.

Yalçin, H., and Ö. Bozkaya (1995), Mineralogy and biogeochemistry of the Quaternary sequence in the Gulf of Izmit (Hersek Burnu-Kaba Burun), in Quaternary Sequence in the Gulf of Izmit, edited by E. Meric, pp. 45-60, Turk. Navy Press, Istanbul, Turkey.

Yalçiner, A., B. Alpar, Y. Altinok, I. Ozbay, and F. Imamura (2002), Tsunamis in the Sea of Marmara. Historical documents for the past, models for the future, Mar. Geol., 190, 445-463, doi:10.1016/S0025-3227(02)00358-4. 